\title{
ANNALS OF IOWA.
}

Vox. I, No. 8.

Des Mones, Iowa, Januahy, 1895.

3D Series. 。

THE PUBLIC SERVICES OF HIRAM PRICE.

BY B. F. GUE.

Hiram Price was born in Washington County, Pennsylvania, January 10, 1814. His father removed to and lived on a farm lying on the banks of the Juniata River, in Mifflin County, about a mile below the little village of Waynesburg. When Hiram was six years old he was sent to a small private school which was kept in the neighborhood as both a day and: evening school. This was long before the public school system was established, and what schools there were in the country settlements were private enterprises, sustained by private subscription and kept by the old-fashion traveling country school teachers, who were then mostly men. School books, as well as all kinds of books, magazines, and even newspapers, were not by any means plenty in those days in farm houses, and were among the luxuries that few were able to secure. Mr. Price, in recalling the memory of his earliest school days, says: "I still have a vivid recollection when a little boy of seven of coming home from the night-school alone, the river on my right and the heavily wooded hills on my left, dark and gloomy, making a lonesome walk for a small boy. On. Saturday afternoons, small as I was, I well remember pad-. dling a canoe along the river near the shore to a favorite fishing place in the shade of some great trees, where I anchored. my boat with a rope attached to a large stone and spent many an hour alone-angling for the sun-fish." The school days $8-1$ 
lasted but from two to three months of the year, and boys were brought up to make themselves useful at farm work as soon as they were large enough to help at any kind of labor. Young Hiram had a taste for reading from the time he was eight years old, and on one of his horse-back ricles to the distant mill with a bag of wheat thrown over the back of the animal, he made the acquaintance of an old man who was willing to lend him some books to read. He thus got "Plutarch's Lives," "Rollin's Ancient History," and other books, which he read evenings after the day's work was done, by the light of a tallow candle. In this way the farmer's boy got his first knowledge of the great world outside and began to acquire a thirst for knowledge that a few years later took him from the farm. When he was sixteen years old he got a position in a country store at a salary of twenty-five dollars a year, and board. At the end of eighteen months he had mastered the art of book-keeping by single entry, and his salary was rnised to $\$ 200$ a year. Brought up to habits of industry and the most rigid economy, the young man had the courage to marry the girl of his choice, Miss Susan Betts; when he was twenty, and getting a salary of but $\$ 300$ a year. But he knew he could live somehow and keep his expenses within his earnings, which he did, never running in debt. Years afterward when he had won fame and fortune in the West he wrote to young men: "The world owes no man a living until he bas earned it. Industry and economy are worth more in the battle of life than genius or wealth, or influential friends or relations. The industry and economy become a part of the individual, and cannot be taken from him without his consent. The others may all leave him whether he consents or not."

The following extract from a private letter reveals the condition financially of the young man when he ventured to take the most important step in his life: "I was twenty years old when we were married and our combined capital was $\$ 145$. So that the contract for life between us had no mercenary tinge to mar its harmony or engender strife. For over fifty years we were one in purpose, one in effort, one in hope. We took 
counsel of each other on all subjects relating to our affairs; our efforts and aims were one. Our comforts and our cares were joint stock and common property."

After several years of hard work and rigid economy they had accumulated a capital of $\$ 2,000$, which was invested in a piece of real estate. But the title proved defective and the hard earnings were lost. Undismayed by this misfortune, they decided to move to the far West and begin again in a new country. In 1844 they moved to the Territory of Towa and settled at the little village of Davenport, which then had about 800 inbabitants. When Mr. Price decided to open a little store in the frontier village where he expected to make his future home he had only about a hundred clollars in money. A historian of early times in Davenport writes of him at this time as follows: "His sunll pecuniary resources were supplemented by a valuable capital of another kind. What he lacked in money was made up in other possessions of grenter valuehe had youth, energy, perseverance, business tact, stern integrity, was rigidly temperate and conscientious in all his transactions." Could a young man have a better equipment for success in life, starting at the foot of the ladder? Such a man was sure to succeed, and in a few years he had established an excellent business reputation and won the confidence and esteem of the community in which he lived. In 1847 he was elected first School Fund Commissioner of the county under the State organization, which had been establisbed the year before. The next year he was elected Recorder and Treasurer for Scott County, and was continued in this responsible position for eight years, serving with the utmost fidelity until he declined a re-election.

Mr. Price has always been a radical and determined oppo- nent of the use and sale of intoxicating liquors, freely giving his time and money to promote temperance movements and. organizations. As early as 1847 he was instrumental in establishing a Division of the Sons of Temperance in Davenport. In February of the next year he was the most influential leader in organizing a Grand Division of the Sons of 
Temperance for the State. He was for many years at the head of that organization, and for a long period was annually chosen to represent it in the National Division of North America. In 1854 a movement was made by the temperance workers of Iowa for the establishment of a "Maine Law League," the object of which was to arouse and influence the people of the State to demand the prohibition by law of the sale of intoxicating liquors. Neal Dow, the distinguished temperance apostle of Maine, had in 1851 secured the enactment of such a law in his State, and it had wrought a great reform from the evils of intenperance, and the temperance people of many of the Northern States had organized for the purpose of securing similar legislation. When the "State Alliance" was organized in Iowa, Hiram Price was by common consent made its first President, for he had by this time become recognized by the temperance workers of Iowa as an untiring, uncompromising and fearless leader in the cause. It was determined to urge the enactment of a prohibitory law at the approaching session of the Eegislature and bring all possible influence to bear to secure a law that would be effective. Hiram Price, David S. True and John L. Davies, of Davenport, were the three men.selected to draft a bill to be presented to the Legislature. They met at Mr. Price's office and there devised and put in legal form the bill which was afterwards enacted into the first Iowa Prohibitory Liquor Law. Dr. Amos Witter, a Democratic Representative from Scott County, was selected to take charge of the bill, and he introduced it promptly in the House on the 13 th of December, 1854. It met with most determined opposition at every stage of progress, but finally passed both houses and received the approval of Governor Grimes. The only important change in the bill as drafted by Messrs. True, Price and Davies, was that which submitted the act to a vote of the electors of the State at the April election, for approval or rejection. The friends of prohibition opened an active campaign and secured the adoption of the Prohibitory Law by a majority of nearly 3,000.

A determined organized effort was at once made by the 
liquor interest in many of the larger towns of the State to defeat the enforcement of the new law, and the Grand Division of the Sons of Temperance decided to establish a paper in the interest of enforcement. The new paper was established at Davenport and called "The Temperance Organ." Hiram Price was the leading spirit in the enterprise and upon him devolved its editorial management.

That it was courageous, aggressive and able under his direction, it is hardly necessary to state. The first number, which is before me, is a handsomely printed seven-column paper having for its motto, "Be Just, and Fear Not." The leading editorial article thus announces the mission of the new paper: "The money and influence of the brotherhood of liquor dealers and their sympathizers are at work for the repeal of the law. The press - that mighty engine for good or evilhas in many instances been subsidized to aid in the accomplishment of this object; and while this has been the case, not one paper in the whole State of Iowa was found to breast the torrent, except incidentally. This state of affairs called loudly for an organ through which the temperance people of Iowa can be heard-a paper whose great object should be to defend our Prohibitory Liquor Law against its enemies, and to refute the slanders and false charges made against it. We shall ask but one question in all matters pertaining to subjects discussed in this paper, and that is, is it right? And if satisfied of this, if persuaded that the cause of justice and humanity will be subserved by it, we shall go ahead without reference to consequences or policy. We will assist to the best of our ability to place demagogues where they belong, and to sweep from existence grog-shops of every size and shape, until the face of this green earth shall know them only as things that were. We are not rich enough to disregard the known wants and wishes of the people, nor are we poor enough to be bought by place and power."

With such a pure and noble purpose did this new paper start out.

In writing of this enterprise thirty years later, Mr. Price 
says: "The music made by that 'organ' may not have been very artistic, but no one could fail to understand the character of the tunes. It was published a year and a half, when my money gave out, and the music so far as that organ was concerned ceased. In return for the time and money I expended, I obtained a large addition to my istock of experience. Among. the large chunks of knowledge that $I$ acquired in this newspaper enterprise was the fact that it is not always the men who make the loudest professions and longest prayers who are the best Christians. Thousands of people are willing to talk and even pray for temperance; but comparatively few are willing to pay for it."

The prohibitory law was to gointo effect on the 4th of July after its enactment, and the saloon men had made threats of violence against any one who attempted to enforce it in Daven. port. Mr. Price and other leaders of the temperance societies had often received letters threatening their property and lives if they undertook to close the saloons. Under the lead of Hiram Price preparations were quietly made to reinforce the officers executing the law in a manner that would be most. effective with law-breakers.

Application was made to the military authorities for arms, which resulted in securing a brass six-pounder and fifty-four muskets with bayonets and cartridges. It soon became known that arms had been secured and the saloon keepers and their friends threatened to capture them. They secretly organized a crowd in Davenport which was'strongly reinforced by their friends in Rock Island. At the hour agreed upon they came together on the 4th of July with the avowed purpose of capturing the arms, and directed their line of march towards the place where the cannon was kept. Many of the temperance guard were absent attending celebrations, but Hiram Price happened to be down town and heard the threats of the gathering mob. Hastily securing some powder and bullets he hurried to where the cannon was kept, warning out such of his friends as he met on the streets. Thirteen determined men were soon at the rendezvous and had barely time to get their 
field piece loaded and in position before the mob was seen advancing upon them about 200 strong. It was a moment of intense excitement. The cannon was in position to sweep the street upon which the mob was advancing, and supported by thirteen cool, determined men with loaded muskets and fixed bayonets. Mr. Price was in command, and as the mob advanced he gave his orders to his little band to make no movement until he discharged his revolver - then to fire the cannon, and immediately re-load and fire again, then use the bayonets. Price then slowly walked ont towards the advancing crowd, presented his revolver, and ordered the howling mob to halt! To his surprise they stopped. Pointing towards his little command, he addressed the crowd in the following words: "That cannon is loaded with bullets to kill. When I fire this pistol that cannon will be fired." Marking a line across the street, he continued: "If you cross this line I shall fire this pistol! You have fair warning-if you disregard it you must take the consequences."

The mob hesitated, the front rank began to fall back, and in a few minutes they retired to a safe distance. While there was no man living more cordially hated by them than Hiram Price, they knew that he aluays kept his promises. That ended the attempt to disarm the prohibitionists, but it by no merns terminated the contest between the opposing forces.

To the day that Mr. Price removed from the State he never ceased to use his influence and contribute of his means to sustain the law he was so largely instrumental in placing apon the statute books of Iown.

He has never wavered in his lifelong warfare on saloons, has never hesitated to strike hard and heavy blows at crimes against law and society, and has never witheld the expression of his enrnest convictions from considerations of policy or fear of consequences, personally or politically.

When others became lukewarm or discouraged, he remained firm; when party policy dictated compromise with the saloon interest, he raised his voice and wielded his pen with the oldtime vigor of youth in protest. When the history of Prohibi- 
tion is written for Iowa, no name will rank higher among the leaders and unfinching advocates of the cause than Hiram Price.

In 1853 a railroad was projected from Chicago westward to some point on the Mississippi River. Work had been begun upon the eastern end of it, and the citizens of Davenport held a conference for the purpose of inducing the company to locate its line through Rock Island, Davenport, across Iowa westward to Council Bluffs. Mr. Price was chosen to wisit the chief towns along the proposed route and get them interested in the project. This was the initial movement which resulted, later in building the great Rock Island Railroad through Iowa, and on westward toward the Pacific Ocean.

In 1869 a railroad was projected from Davenport north. ward, and Mr. Price was chosen President of the company. He put $\$ 10,000$ of his own money and all of his unsurpassed energy into the enterprise, and built the road to Maquoketa and equipped it. He also built a portion of the branch running northward via Wheatland. It is a notable fact that there were no jobs for friends or favorites in the construction and equipment of these roads. Everything was done on principles of the strictest integrity and in the interest of the stockholders who had furnished the money to build the road. No combination of influential parties was able to swerve the President from the faithful execution of the trust placed in his charge. While the road was beneficial to Daven port and the country it passed through, it was not a profitable investment to the men who furnished the money to build it and $\mathrm{Mr}$. Price never realized a dollar from the enterprise.

Mr. Price had been a Democrat all the early years of his life and after he settled in Iowa was an active member of that party. He was the Democraticl candidate for the first offices he held in this State. But the position his party had gradually been taking for several years in defense of the encroachments of slavery in the new Territories had alienated him from it. He was not in härmony with a majority of its members on the license of the sale of intoxicating liquors, and with thousands 
of other Democrats in the Northern States was ready and anxious to ally himself with a party whose principles accorded more nearly with his own convictions of right and wrong.

On the $22 d$ of February, 1856 , there assembled at Iowa City a notable body of representative men of the State in response to a call for the organization of a Republican party. Former members of the Whig, Democratic and Anti-Slavery parties came together to make common cause against the aggressions of the slave power. Old party ties were severed, and $a$ union of all opposed to the extension of slavery was the object of the convention.

The advocates of the Prolibitory Liquor Law under the lead of Hiram Price made a vigorous effort to secure in the platform to be adopted a recognition of their cause. The German voters, who were numerous in several of the river counties, were almost a unit in opposition to slavery and were ready to leave the Democratic party and unite with a new organization making common cause against the extension of slavery into the new Territories. But they were also opposed to the Prohibitory Liquor Law.

It was contended by those who were opposed to an indorsement of prohibition, that the paramount issue was opposition to the extension of slavery, and that this convention was called for the purpose of organizing all who held views in common on that subject into a political body to co-operate with the then rising Republican party in the Northern States in resisting the demands of the slave power. That no other issue of a local character ought to be permitted to divide the anti-slavery people or alienate a portion of them from the new party. That with union and harmony the new party could control - the State and secure anti-slavery representatives in Congress, but by introducing other issues fatal divisions, would ensue, leading to defeat. The advocates of prohibition met these objections and arguments with powerful appeals to the delegates to do right, and trust to the fidelity of the voters to give them victory.

Hiram Price was chairman of the Scott County delegation, 
the largest in the convention, and was the leader of the Prohibitionists. Under his inspiration an able and vigorous contest was made for the incorporation of prohibition into the platform of the new party. But a majority of the delegates were of the opinion that the only issue should be made on slavery extension, where all could agree and work in harmony.

The Prohibitionists acquiesced in the decision of the majority, and a new party was organized which was destined to rule the State and Nation for a third of a century.

During his residence in Iowa Mr. Price had been successful in his business enterprises, and in the official positions he had held, and had acquired the reputation of an able financier. When the act of the Legislature of 1858 providing for a system of State banks took effect, he represented one of the branches, and after the first year was chosen President of the State Bank, which office he held until that system was superseded by the National banks in 1865. No better State bank system has ever been devised than this Iowa law brought into existence. Many of the fentures of the National banking system were suggested by the Iowa law and had here been found by the experience of seven years of successful trial to be well adapted to the exigencies of the business. The men who had organized the Iowa banks and supervised their business during. the period of their successful career, retired with the reputation of able and trustwortby financiers.

When the great Rebellion suddenly came upon the country, the Northern States were entirely unprepared for war. 'They were generally destitute of efficient military laws to meet such an emergency, and no money was available to provide for the extraordinary expenses that must be incurred in furnishing troops in response to the calls of the National Goverument. While Governor Kirkwood was waiting for funds from the sale of State bonds authorized by an extra session of the Legislature, two Iowa regiments had hastened into the service. The young men composing these regiments had left their homes on short notice and generally with very little money to supply their wants. The State undertook to pay the sol- 
diers, until they were mustered into the United States service but no money had yet been realized from the bonds. Hiram Price had learned of the destitution of the boys and wrote to Governor Kirkwood: "Governor: Cannot something be done immediately to furnish these men some money? If taken sick many of them have not money to buy an orange." To this the Governor replied: "You are right, Mr. Price, but what can we do? We have no money." In reply Mr. Price wrote: "I can raise a few thousand dollars and I feel that something ought to be done at once, if it is ever so little, to show these men that they are not forgotten."

This correspondence bronght about a conference which resulted in the speedy raising of $\$ 33,000$. Of this sum Hiram Price raised $\$ 22,000$ and Ezekiel Clark of Iowa City raised $\$ 11,000$, becoming personally responsible for these amounts.

Governor Kirkwood gratefully accepted the money tendered by these two patriotic citizens and promptly commissioned them to proceed to Missouri where the regiments were engaged in active service and make the first payment to the soldiers. It was a hazardous mission that Price and Clark undertook as the portions of the State where the Iowa regiments were stationed were infested with Confederate recruits bnstening to join General Sterling Price's rebel army.

The $2 \mathrm{~d}$ Iowa regiment was found guarding bridges on the Hannibal \& St. Jo. Railroad, and $\$ 11,000$ was paid to them. Soon after, Mr. Clark, who was acting Quartermaster General, was called away on urgent business, and Mr. Price proceeded alone to find the 1st Iowa regiment, which was in Central Missouri, in General Lyon's command. . It was just before the battle of Wilson's Creek. The whole State was at this time in a condition of anarchy. Many of its public officials and leading citizens were actively engaged in enlisting soldiers for the Confederate service, obstructing railroads and organizing guerrilla bands to destroy Government property, and cut off recruits and supplies for the Union armies. Hiram Price now began his journey to find the regiment. When he approached Jefferson City a section of the railroad was found to be in the 
hands of the rebels, and a portion of his journey was made on foot through the enemy's country. But he succeeded in reaching Booneville in safety and there found and paid $\$ 11,000$ to the 1st Iowa Infantry, a few days before the battle of Wilson's Creek. Returning to Keokuk he paid the 3d Infantry $\$ 11$,000 before it left for the South.

When the first arms were sent to Burlington by the General Government to aid the Governor of Iowa in expelling the rebel bands from Missouri who were plundering the people of the border counties, the express company held them for $\$ 900$ charges which the Governor had no money to pay. When'the first bales of blankets for Iowa soldiers were sent to Davenport, they were held for $\$ 500$ charges for transportation. In these and other financial emergencies Hiram Price came promptly forward and raised the money upon his own personal credit, and loyally stood by Governor Kirkwood in those perilous and critical times. He never hesitated from prudential considerations, as so many thousands of monied men did, but freely risked his fortune as well as his life whenever emergencies required it. Few citizens of Iowa, of the present generation, will ever know how loyally such men as Hiram Price, Ezekiel Clark, J. K. Graves, W. T. Smith, W. F. Coolbangh, and a few other able financiers came to the aid of our State Govern-. ment in those trying times. Young men were plenty in those days who were willing to risk their lives for their country, but capitalists who were as ready to risk their fortunes in behalf of the same good cause were not numerous.

During the darkest days of the rebellion, when the first draft had been ordered to reinforce the Union armies, Henry Clay Dean held a meeting in Davenport. The hall was crowded with disloyal people who were known as "Copperheads." Dean's speech was undoubtedly thë vilest denunciation of Lincoln's administration ever uttered in Iowa. A little group of Republicans occupiedl a seat in an obscure corner of the room, among whom was Hiram Price. I remember one part of Dean's terrific assault upon the Government was substantially in these words: "There is a: singular resemblance 
between Claudius Nero and Abraham Lincoln. Nero put Christians to death under false pretenses to gratify the worshippers of the Pantheon. Lincoln corrupted one part of the church to engage in warfare with the other part, and burned twelve hundred houses of worship; mutilated graveyards; dragged ministers from their knees in the very act of worship; tied them up by their thumbs; had their daughters stripped naked by negro soldiers, under command of white officers."

When Dean had finished his venomous speech Hiram Price sprang up on a bench, every fiber of his loyal heart quivering with indignation, as his clear voice rang out: "Mr. President, may I be permitted to reply to Mr. Dean?" "No," shouted Dean, "we want none of your black abolition speeches here. The meeting is adjourned-boys, let's go," and he started for the door, followed by his friends. Hiram Price shook his hand at the retreating crowd and exclaimed in a voice that rang out like a bugle blast: "Henry Clay Dean, I will give you ten dollars if you and your gang will hear me ten minutes in reply to your infamous harangue." But nothing could stop the stampede. They knew. Hirnm Price too well to permit him to pour the hot shot upon their heads. Dean, without replying, led the wild flight into the street out of reach of the impending excoriation.

All through the anxious years of the war Mr. Price was one of the pillars of strength to our State Government in the herculean work it had to do. His time, money, services and counsel were always freely given, with a promptness which inspired confidence and strengthened the timid and wavering. It was during this period that be was first called upon to represent the Second District in Congress. In the dark days of 1862 he was nominated by the Republicans, and at the close of a vigorous and aggressive campaign was elected by a majority of over 3,500 . As a member of Congress Mr. Price was an earnest supporter of the most energetic war measures, as well as of all legislation required to strengthen the credit of the National Government. 
In 1864 he made an able speech in support of the bill to establish The Freedmens' Burean.

At the Republican State Convention held in Des Moines in June, 1865, Edward Russell, a delegate from Scott County, and editor of The Davenport Gazette, offered an amendment to the platform reported by the committer on resolutions, which aroused a warm discussion. The amendment was as follows: "Therefore, we are in favor of amending the Constitution of our State by striking out the word white from the article on suffrage."

The purpose of the amendment was to remove the last remnant of race discrimination from the laws of Iowa. Many of the timid delegates were alarmed and made strong efforts to persuade Mr. Russell to withdraw his resolution But he refused, and made a vigorous defense of his measure. 'So radical an anti-slavery man as J. B. Grinnell feared that its adoption, which meant negro suffrage, would defeat the Republican ticket. Hiram Price took the floor after several delegates had opposed the amendment as impolitic, and made one of the great speeches of his life.

"The Republican party," said he, "is strong enough to dare to do right, and cannot afford now, or at any other time, to shirk a duty. The colored men, North and South, were loyal and true to the Government in the days of its great peril. There was not a rebel or traitor to be found among them. 'They ask the privilege of citizenship now that slavery has been forever banished from our country. Why should the great freedom-loving State of Iowa longer deny them this right? Not one reason can be given that has not been used to bolster up slavery for the past hundred years. The war just closed has swept that relic of barbarism from our land; let the Republican party have the courage to do justice. I have no fear of the result in a contest of this kind. We shall carry the election and have the satisfaction of wiping out the last vestige of the black code that has long been a disgrace to our State." After the lapse of nearly thirty years it is impossible to give anything like a graphic report of this speech-for it 
was entirely impromptu, and never reported or published. But those who heard it will never forget the fervid eloquence, the sledge-hanmer logic, or the powerful and irresistible appeal poured forth in a torrent of righteous indignation that has seldom been surpassed. The timid delegntes were shamed - into silence by the eloquence of the fearless leader, and right prevailed over policy. The Russell amendment was adopted and carried into eftect by the required legislation, thus wiping off from the statute books of Iowa the last remnant of race discrimination.

Mr. Price was one of the founders of the Soldiers' Orphans' Home at Davenport, which cared for the children of soldiers who gave their lives for their country in war. times, and has always remained one of its most influential supporters.

He remained in Congress for three terms, giving loyal support to the measures of reconstruction as enacted by the Republican majority following the suppression of the great rebellion. At the close of his third term he declined a reelection. In 1876 he was again sent to Congress from his old district, remaining there two terms.

On November 7, 1877, Mr. Price made a speech in the House strongly adrocating the resumption of specie pryment. On the 15th of the next January he made an able speech in favor of remonetizing silver and making it a legal tender in payment of debts. In the course of his argument he snid: "No nation attempts to demonetize silver and adopt the gold standard while sle is a debtor nation. But when a nation becomes a creditor nation, her interest may be to have gold alone as the standard, and the dearer they can make the gold the better for them. The effect is to make money dear and labor cheap, and no amount of special pleading or sophistry can avoid this stubboin fact. We. who advocate the restoration of silver as it was prior to 1873 are not repudiators. We seek to avoid no contracts or obligations; we want no silver dollar that is not as good as any gold dollar. The acts of 1873-74 took from our people what for long years and under all circumstances had been-a sound, reliable and current coin 
of the nation, and now in the name of the oppressed and suffering industries of the country we demand the restoration of what was wrongfully taken from us. We are not speaking of legislation for bullion, either gold or silver. We are legislating for gold and silver coined, and made the legal-tender money of the nation as contemplated by the Constitution of the United States. We are laboring to get back the dollar that has been tried in every condition, and under every variety of circumstances, in this country, and never found wanting."

Iowa has been unusually fortunate and influential in its representatives at Washington for more than a quarter of a century. But it never had a stronger array of gen uine statesmen than during the closing years of the great rebellion. 'James Harlan, James W. Grimes, James F. Wilson, Hiram Price, William B. Allison, Josiah B. Grinnell, John A. Kasson and Asabel W. Hubbard made an array of talent and influence that has never been surpassed by any State in its Congressional delegation.

A paper published at his old home says of Mr. Price's religious associations: "A life-long Methodist, he has been an active supporter and liberal contributor to the church of his choice. In early days when the members were few in number, and all were pretty close to the foot of fortune's financial ladder, Mr. Price agreed to do all the sexton's work for one year, on condition that no collections should be taken up for incidental expenses. He swept out the frontier mud and cleaned the smoky. oil lamps with the same vigor and thoroughness that have since characterized his work as a banker, railroad president, congressman, Indian commissioner and philanthropist." At the fiftieth anniversary of the church, in 1889, he said: "During my fifty-seven years as a member of this church I have been sexton, steward, trustee, class-leader, Sunday-school superintendent, delegate to two General Conferences, and am just as proud of having been sexton as of the other positions."

In 1881, at the close of his last term in Congress, Mr. Price was appointed by the President Commissioner of Indian 
Affairs. He entered upon the work of his new position with his usual zeal and energy, and for four years labored to better the condition of the Indians, and reform some of the methods of dealing with them by the Govermment. He was now nearly seventy years of age, and had since boyhood led an active life, toiling early and late, in both private and public affairs. Whatever business claimed his attention was prosecuted with untiring vigor and generally led to success. For more than thirty years he had been a leader in reform, financial and political affairs in the State. From youthful poverty he had won a competence; in the temperance movement he was conceded the highest rank; in financial enterprises he had achieved great success; in official life his record was above suspicion, and his influence was second to none in the State.

As a public speaker Mr. Price never resorted to the artifices of the professional orator. He did not care to amuse his audience with a stock of anecdotes sandwiched in at regular intervals to ruise a laugh or win applause. He never "posed" for effect, nor did he ever seek occasions to make speeches for the purpose of advertising himself. When he spoke in public it. was certain that he had something to say, and he went at it in the most direct and straightforward manner. There was no policy, no honeyed phrases to please the ear and conceal an opinion. He used the plainest English, looking his audience squarely in the eyes; he held their closest attention and aroused the highest degree of enthusiasm by his fearless and earnest utterances. No one could mistake his position. It was always taken and maintained with a positiveness that left no room for doubt. He never waited to catch the drift of the popular breeze, but always led off, prompted only by his convictions of right and wrong. He was never a compromiser, but on the contrary was one of the most vigorous fighters of the times. When overborne by the majority he acquiesced gracefully, not because he was convinced that the decision was right, but because he was loyal to the fundamental principle of our republican government-that the majority should rule. He made bitter enemies in his life-long war against evil-doers, $8-2$ 
but intense as was their hatred, they secretly entertained a profound respect for a foe so valiant and sincere.

Mr. Price was often urged to become a candidate for Gov. ernor, by friends who recognized his superb executive ability, but he did not care to enter into a coritest for that exalted position, and is content to live a quiet life as old age approaches. One of his last kindly remembrances of his old Davenport home was a recent gift to the public library of that city. He set aside an amount of money, the interest of which is used to furnish a free reading room with thirty of the best magazines, weekly and daily papers. He also furnished and fitted up a commodious room where the people have free access to the best current literature of the times.

And now past eighty years of age, his mental vigor unimpaired, he is living a quiet life in his Washington home. Our Iowa people remember and honor him for his noble life work in behalf of our great State, and his name will be for all time associated with the stirring events of the brightest pages of its history.

The steel portrait which appears with this article was engraved from a photograph of Mr. Price taken in 1878.

\section{FORT ARMSTRONG.}

BI MRS. MARIA PECK.

Upon the large and beautifully wooded island in the Mississippi now occupied by the splendid piles of solid masonry comprising Rock Island Arsenal, picturesque and solitary, Fort Armstrong once stood.

To ascertain the initial facts underlying the history of the establishment of this military post in 1816 , it is necessary to go back to the earlier years of the century and review the most important incidents upon which was based the claim of 
Copyright of Annals of Iowa is the property of State of Iowa, by \& through the State Historical Society of Iowa and its content may not be copied or emailed to multiple sites or posted to a listserv without the copyright holder's express written permission. However, users may print, download, or email articles for individual use. 